\title{
Control of Brown Rot Decay of Nectarines with $15 \%$ Carbon Dioxide Atmospheres
}

\author{
H. Ahmadi, W.V. Biasi, and E.J. Mitcham \\ Department of Pomology, University of California, Davis, CA 95616-8683
}

\begin{abstract}
AdDitional INDEX wORDs. Monilinia fructicola, controlled atmospheres, fungistatic, storage temperature, Prunus persica
Abstract. Effects of short-term exposure to a 15\% $\mathrm{CO}_{2}$ atmosphere on nectarines [Prunus persica (L.) Batsch (Nectarine Group) 'Summer Red'] inoculated with Monilinia fructicola (Wint.) Honey (causal agent of brown rot) were investigated. Nectarines were inoculated with spores of $M$. fructicola and incubated at $20^{\circ} \mathrm{C}$ for 24,48 or 72 hours and then transferred to storage in either air or air enriched with $15 \% \mathrm{CO}_{2}$ at $5{ }^{\circ} \mathrm{C}$. Fruit were removed from storage after 5 and 16 days and were examined for brown rot decay immediately and after ripening in air for 3 days at $20^{\circ} \mathrm{C}$. Noninoculated nectarines were stored and treated likewise for evaluation of postharvest fruit attributes to determine their tolerance to $15 \% \mathrm{CO}_{2}$. Incubation period after inoculation, storage duration, and storage atmosphere had highly significant effects on fruit decay. 'Summer Red' nectarines tolerated a $15 \% \mathrm{CO}_{2}$ atmosphere for 16 days at $5{ }^{\circ} \mathrm{C}$. Development of brown rot decay in fruit inoculated 24 hours before 5 or 16 days storage in $15 \% \mathrm{CO}_{2}$ at $5{ }^{\circ} \mathrm{C}$ was arrested. After 3 days ripening in air at $20{ }^{\circ} \mathrm{C}$, the progression of brown rot disease was rapid in all inoculated nectarines, demonstrating the fungistatic effect of $15 \% \mathrm{CO}_{2}$. The quantity of fungal cell wall materials (estimated by glucosamine concentration) was compared to visual estimation of decayed area and visual rating of fungal sporulation. The glucosamine assay defined the onset and progress of brown rot infection more precisely than either of the two visual tests.
\end{abstract}

Monilinia fructicola, the causal agent of brown rot, together with M. laxa (Adreh. and Ruhl.) Honey (the cause of blossom blight as well as brown rot) are the major pre- and postharvest diseases of stone fruit in California and elsewhere (Northover and Cerkauska, 1992; Ogawa et al., 1985). The incidence of brown rot decay is usually increased by preharvest rains, accumulation of excess moisture on the fruit, wind, and movement of insect vectors. Application of fungicides and insecticides at proper intervals, careful handling of harvested fruit to avoid wounding, proper sanitation pre- and postharvest, rapid cooling after harvest, and storage at $0{ }^{\circ} \mathrm{C}$ are methods used to decrease disease incidence, increase the lag period of the germination of brown rot spores, and postpone the onset of disease (Osorio et al., 1993; Sommer, 1985). Despite these efforts, postharvest decay can result in significant crop losses (MacNab, 1975; Ogawa et al., 1985).

Development of pathogen resistance to chemical sprays, strong public opinion against the use of synthetic fungicides and insecticides, and health risks involved in their application make other solutions for control of the brown rot disease more desirable. Controlled atmospheres (CAs) enriched with higher than $12 \% \mathrm{CO}_{2}$ have been shown to have fungistatic properties (Kader et al., 1982; Sommer, 1985). DeVries-Paterson et al (1991) found that $\mathrm{CO}_{2}$ inhibited growth of Monilinia fructicola during modified atmosphere packaging of sweet cherries (Prunus avium L.), however, there was no residual effect on decay growth upon opening of the bags. A combination of careful handling, sanitation, and temperature management, with application of high $\mathrm{CO}_{2}$ regimes during shipment, is an attractive management strategy at the present time. Many stone fruit, with the exception of sweet cherries (DeVriesPaterson et al. 1991; English and Gerhardt, 1942), cannot tolerate elevated concentrations of $\mathrm{CO}_{2}$ for extended storage periods (Allen and Smock, 1937; Sommer, 1985). However, their short-term tolerance to CA treatments of $15 \% \mathrm{CO}_{2}$ is unknown.

Received for publication 8 Feb. 1999. Accepted for publication 16 Aug. 1999. Partial support for this project was provided by the University of California Sustainable Agriculture Research and Education Program. The cost of publishing this paper was defrayed in part by the payment of page charges. Under postal regulations, this paper therefore must be hereby marked advertisement solely to indicate this fact.
The objectives of the present study were to examine the tolerance of nectarines to 5 and $16 \mathrm{~d}$ exposures to $15 \% \mathrm{CO}_{2}$ at $5{ }^{\circ} \mathrm{C}$ and to describe the effects on brown rot decay in various stages of development. In addition, a comparison was made between the precision with which a glucosamine assay could describe the onset and development of the brown rot infection and that of the conventional measurements of the size of the damaged area and the degree of sporulation.

\section{Materials and Methods}

Preparation and test of fungal isolate. The $M$. fructicola strain used in this study was a single spore isolate, recovered from decayed nectarines, cultured, and maintained on potato-dextrose agar(PDA) slants at $4{ }^{\circ} \mathrm{C}$ (Sommer et al., 1981). Spores of the isolate were grown on PDA medium for $10 \mathrm{~d}$ under a $12 \mathrm{~h}$ photoperiod [ 20 $\mathrm{mmol} \cdot \mathrm{m}^{-2} \cdot \mathrm{s}^{-1}$ from a $30-\mathrm{W}$, cool-white fluorescent lamp as measured at the level of the cultures by a quantum sensor (LI-190S-1;LICOR, Lincoln, Neb.)] at $22^{\circ} \mathrm{C}$. The pathogenicity of the spores was confirmed on peaches [Prunus persica L. Batsch (Peach Group)] and nectarines at $20^{\circ} \mathrm{C}$ and various inoculum strengths were tested to determine the spore number which resulted in minimal visible decay ( 1 to $2 \mathrm{~mm}$ diameter) after incubation at $20^{\circ} \mathrm{C}$ for $72 \mathrm{~h}$. Conidia were harvested from 10-d-old cultures in sterile distilled water containing one drop of Tween 80 per $100 \mathrm{~mL}$ of water, centrifuged at $2000 g_{n}$, and resuspended in sterile distilled water without Tween 80 . The spore suspension was filtered through four layers of sterile cheese cloth and the spore concentration determined using a hemocytometer. The spore concentration was adjusted with sterile distilled water to $5.4 \times 10^{4}$ spores per milliliter of inoculum. Fruits were inoculated immediately after preparation of the spore suspension.

Preparation and Characterization Of Fruit Samples. 'Summer Red' nectarines were obtained at harvest on 18 Aug. 1994 without any postharvest treatments from the Central Valley of California, and transported to Davis, Calif. Fruit were sorted carefully for uniform maturity, size, and absence of defects and decay. Nine nectarines were evaluated for initial fruit maturity and quality including firmness, soluble solids, titratable acidity, internal condi- 
tion and decay. Fruit tissues were frozen at $-30{ }^{\circ} \mathrm{C}$ for later determination of the background concentration of glucosamine. Remaining fruit were stored at $0{ }^{\circ} \mathrm{C}$ until used.

Fruit InOCULATion. Seventy-two nectarines were injured, each at three positions (the stem end, equator on cheek, and blossom end), to a depth of $\approx 2 \mathrm{~mm}$ with a sterile 200 -mL plastic pipette tip and $10 \mathrm{~mL}$ of inoculum (540 spores) were injected into each wound. For each injury and inoculation, a fresh pipette tip was used and the inoculum was stirred frequently. Inoculations were performed under sterile conditions. The inoculated fruit were then placed in a closed container on a metal screen over water to maintain high humidity, covered, and incubated for $72 \mathrm{~h}$ at $20^{\circ} \mathrm{C}$. After $24 \mathrm{~h}$, the second lot of 72 nectarines were removed from $0{ }^{\circ} \mathrm{C}$ storage and inoculated in the same fashion, and were incubated at $20^{\circ} \mathrm{C}$ for $48 \mathrm{~h}$. On day 3 , the third lot of fruit samples were injured, inoculated as described previously, and were incubated for $24 \mathrm{~h}$ at $20^{\circ} \mathrm{C}$ to develop three groups of fruit with varying levels of brown rot decay development.

Storage Treatments. After the incubation period, all inoculated fruit were transferred to storage at $5^{\circ} \mathrm{C}$. Two atmospheres (air and air enriched with $15 \% \mathrm{CO}_{2}$ ), humidified by bubbling through a water reservoir, were provided to $9.5 \mathrm{~L}$ glass jars with a flowthrough system $\left(37.5 \mathrm{~mL} \cdot \mathrm{min}^{-1}\right)$. Nectarines with different incubation times after inoculation $(24,48$, and $72 \mathrm{~h}$ ) and different atmospheres were placed in separate jars with 12 fruit per jar. There were three replications for a total of 18 jars.

The remaining (noninoculated) nectarines (in $0^{\circ} \mathrm{C}$ storage) were also transferred to storage at $5^{\circ} \mathrm{C}$ in air or air plus $15 \% \mathrm{CO}_{2}$ for fruit tolerance studies. There were three replications for each atmosphere for a total of six jars with 12 fruit per jar. Six fruit were randomly selected and removed from each jar after $5 \mathrm{~d}$ treatment and the jars were immediately resealed. The remaining six fruit were removed from the jars after $16 \mathrm{~d}$.

EVALUATION OF BROWN ROT DECAY. Following removal of nectarine samples from storage at $5^{\circ} \mathrm{C}$ for 5 or $16 \mathrm{~d}$, three fruit per jar were evaluated immediately and three fruit were evaluated after $3 \mathrm{~d}$ of ripening at $20^{\circ} \mathrm{C}$. The progress of brown rot decay was recorded as the percentage of affected epidermis tissue on each nectarine. Average diameter of decayed tissue at each inoculation area (three areas/fruit) was measured and the total decayed surface area was calculated for each fruit. Total decayed surface area was divided by the surface area of the fruit (calculated from the average diameter, assuming a spherical fruit), and multiplied by 100, defining the percentage of affected surface area of the fruit. For a few samples, the decayed area could not be defined precisely (the boundaries of the decayed area had merged because of the progress of disease); therefore, a visual approximation of the affected area was recorded.

Sporulation of brown rot decay was scored for each decayed area, using a subjective scale of 0 to 4 (none, slight, moderate, severe, and very severe sporulation, respectively). After visual analysis of disease progression, one fruit from each replication was randomly selected, weighed, chopped, and frozen at $-30{ }^{\circ} \mathrm{C}$ for analysis of glucosamine content at a later date.

QUANTIFICATION OF FUNGAL CELL WALL (GLUCOSAMINE ASSAY). Frozen nectarines were thawed rapidly, weighed, and homogenized with a Polytron (Brinkmann Instruments, Westburg, N.Y.) on ice; small volumes of distilled water were added as necessary. The equivalent of 0.5 to $4 \mathrm{~g}$ (generally $2 \mathrm{~g}$ ) of homogenized fruit tissue was transferred to a 15 $\mathrm{mL}$ graduated conical, glass centrifuge tube resting on ice.

The glucosamine assay used to quantify fungal cell wall materials in fruit tissues was first described by Ride and Drysdale (1972), modified by Jarvis (1977) and Bishopet al. (1982) and also modified slightly in our laboratory. Fruit samples were diluted with $10 \mathrm{~mL}$ of 1 methanol : 1 chloroform (v/v), stirred with a glass rod for five min, and centrifuged $\left(1.5 \times 10^{3} g_{n}, 10 \mathrm{~min}\right)$. Pellets were diluted with nine volumes of anhydrous acetone, mixed for $5 \mathrm{~min}$ and centrifuged as described above. Pellets were resuspended in acetone and centrifuged again. The pellets were dried overnight in a vacuum oven at $40^{\circ} \mathrm{C}$, suspended in 4 $\mathrm{mL}$ of concentrated $\mathrm{KOH}(120 \mathrm{~g} \mathrm{KOH} / 100 \mathrm{~mL}$ distilled water) and autoclaved at $121^{\circ} \mathrm{C}$ for $15 \mathrm{~min}$. Chitosan was precipitated by adding 10 $\mathrm{mL}$ ( 2.5 volumes) of $75 \%$ ethanol at $0{ }^{\circ} \mathrm{C}$. A $0.9 \mathrm{~mL}$ celite (JohnsManville, Denver, Colo.) suspension ( $1 \mathrm{~g}$ in $20 \mathrm{~mL}$ of $75 \%$ ethanol) was layered on top of each sample. Tubes were centrifuged for $10 \mathrm{~min}$ as described above. Pellets were washed with $10 \mathrm{~mL}$ of $40 \%$ ethanol $\left(0^{\circ} \mathrm{C}\right)$ and recentrifuged for $10 \mathrm{~min}\left(1.5 \times 10^{3} \mathrm{~g}_{\mathrm{n}}\right)$. Pellets were washed twice with distilled water $\left(0^{\circ} \mathrm{C}\right)$ and recentrifuged. Pellets in each tube were adjusted to $1.5 \mathrm{~mL}$ with distilled water, then $1.5 \mathrm{~mL}$ of $5 \%$ (w/v) $\mathrm{NaNO}_{2}$ and $1.5 \mathrm{~mL}$ of $5 \% \mathrm{KHSO}_{4}$ were added to each centrifuge tube. Tubes were stirred for $15 \mathrm{~min}$ and centrifuged for $5 \mathrm{~min}$ at $1.5 \times 10^{3} \mathrm{~g}_{\mathrm{n}}$. Two samples (replications) of $1.5 \mathrm{~mL}$ of the supernatant were removed. To each sample, $0.5 \mathrm{~mL}$ of $12.5 \%(\mathrm{w} / \mathrm{v}) \mathrm{NH}_{4} \mathrm{SO}_{3} \mathrm{NH}_{2}$ was added and after 5 min of stirring, $0.5 \mathrm{~mL}$ of $0.5 \% \mathrm{MBTH}$ (3-methyl-2-bezothiozolone hydrozon) was added. The mixture was heated in a boiling water bath for $3 \mathrm{~min}$, cooled, and $0.5 \mathrm{~mL}$ of $\mathrm{FeCl}_{3}(0.5 \% \mathrm{w} / \mathrm{v})$ was added and mixed well for $30 \mathrm{~min}$ at $20^{\circ} \mathrm{C}$. Absorbance of the samples at $650 \mathrm{~nm}$ was recorded (Gilford response TM spectrophotometer, Obelin, Ohio).

Standard solutions of glucosamine- $\mathrm{HCl}$ were prepared using the method described by Bishop et al. (1982). The glucosamine concentration of each inoculated fruit sample was calculated from the linear region of the standard curve (8 point linear standard curve: $0,0.5,1.0,2.0,3.0$, 5.0, 7.0, and $10.0 \mathrm{mg}$ ) and expressed as micrograms glucosamine per gramoffruitsample. The glucosaminecontent of sixinitial,noninoculated control fruit were calculated, and the average glucosamine concentration of these samples was subtracted as background from those of inoculated fruit (adjusted glucosamine concentration).

Fruit QuAlity AND CONDition. After 5 and $16 \mathrm{~d}$ storage, six noninoculated nectarines were removed from each jar. Three fruit were evaluated immediately and three were evaluated after ripening $3 \mathrm{~d}$ at $20^{\circ} \mathrm{C}$. Firmness of each fruit was measured on each cheek using an Ametek penetrometer (J. Chatillon \& Sons, Greensboro, N.C.) fitted with an 8-mm-diameter probe. Nectarine juice was extracted from three slices (wedge shape cut from stem to blossom end), one slice from each of the three fruit in each replication (jar). Juice was titrated to $\mathrm{pH} 8.2$ with $\mathrm{NaOH}$ and percent titratable acidity (TA) was calculated based on malic acid equivalents. Total soluble solids (TSS) was measured with a temperature-compensated refractometer (American Optical Corp., Buffalo, N.Y.).

All noninoculated fruit samples were examined carefully for external discoloration and decay. Fruit were cut and theirinternal tissues were also examined for discoloration, injuries, and mealiness. Tissues of six fruit from the noninoculated 5- $\mathrm{dCO}_{2}$ treatment and three fruit from the initial lot at harvest which showed no visual signs of decay were frozen for fungal cell wall analysis as controls (background).

EXPERIMENTAL DESIGN AND STATISTICAL ANALYSIS. A completely randomized design with a factorial arrangement of treatments was used for all experiments. Data were subjected to analysis of variance (ANOVA) using SAS General Linear Model procedures (SAS Inst. Inc., Cary, N.C.). All interactions were also included and compared.

For all quality parameters tested, means were compared among storage treatments, storage durations, and jar replication. Scores of brown rot decay were handled in the same fashion across storage treatments, storage durations, periods of inoculation, and jar replication. Means of the adjusted glucosamine concentration of inoculated fruit samples were tested among storage treatments and their durations and periods of inoculation. Means of the above visual tests of the brown rot 
Table 1. Analysis of variance for area of infected epidermis, sporulation score, and fungal cell wall material (glucosamine) of 'Summer Red' nectarines inoculated with Monilinia fructicola, and postharvest quality attributes [firmness, total soluble solids (TSS), and titratable acidity (TA)] of noninoculated fruit.

\begin{tabular}{|c|c|c|c|c|c|c|c|}
\hline Source & df & $\begin{array}{c}\text { Infected skin } \\
\text { area }(\%)\end{array}$ & $\begin{array}{l}\text { Sporulation } \\
\text { score }\end{array}$ & $\begin{array}{l}\text { Glucosamine } \\
\text { content } \\
\left(\mathrm{mg} \cdot \mathrm{g}^{-1} \text { fresh wt) }\right.\end{array}$ & $\begin{array}{l}\text { Firmness } \\
(\mathrm{N})\end{array}$ & $\begin{array}{l}\text { TSS } \\
(\%)\end{array}$ & $\begin{array}{l}\text { TA } \\
(\%)\end{array}$ \\
\hline Atmosphere (A) & 1 & $* * * *$ & **** & $* * * *$ & $*$ & NS & NS \\
\hline Days in storage (D) & 4 & $* * * *$ & $* * * *$ & $* * * *$ & $* * * *$ & $* * * *$ & $* * *$ \\
\hline $\mathrm{A} \times \mathrm{D}$ & 4 & $* * * *$ & $* * * *$ & $* * * *$ & NS & NS & NS \\
\hline Inoculation time (I) & 2 & $* * * *$ & $* * * *$ & $* * * *$ & --- & --- & --- \\
\hline $\mathrm{I} \times \mathrm{A}$ & 2 & $* *$ & NS & $* *$ & --- & --- & --- \\
\hline $\mathrm{I} \times \mathrm{D}$ & 8 & $* * * *$ & $* * * *$ & $* * * *$ & --- & --- & --- \\
\hline $\mathrm{A} \times \mathrm{D} \times \mathrm{I}$ & 8 & $* * * *$ & $* * * *$ & $* * *$ & --- & --- & --- \\
\hline
\end{tabular}

lesion were nonsignificant among jar replications. Means of the main effects were partitioned using Duncan's multiple range test.

\section{Results}

EFFECT OF 15\% $\mathrm{CO}_{2}$ ON BROWN ROT DECAY DEVELOPMENT. Analysis of variance of percent infected epidermis area and sporulation score data for $M$. fructicola revealed that the two atmosphere treatments (air and air plus $15 \% \mathrm{CO}_{2}$ ), days in storage $(0,5,16,5+3$, and $16+3$ ), three inoculation times $(24,48$, and $72 \mathrm{~h})$, and their interactions were highly significant (Table 1). The one exception was the inoculation time and atmosphere interaction for sporulation score. The three jar replication environments were not significant. Analysis of variance of glucosamine content released from fungal cell wall chitin of inoculated fruit revealed that the storage atmosphere, days in storage plus ripening, inoculation time, and their interactions were highly significant (Table 1).

Decay development during storage in fruit inoculated and held $72 \mathrm{~h}$ at $20^{\circ} \mathrm{C}$ before storage at $5^{\circ} \mathrm{C}$ was excessive, but was much lower in fruit stored in air enriched with $15 \% \mathrm{CO}_{2}$ than air alone (Fig. 1). After 5 or $16 \mathrm{~d}$ at $5{ }^{\circ} \mathrm{C}$, the size of lesions on the epidermis of inoculated fruit stored in $15 \% \mathrm{CO}_{2}$ was almost half the size of lesions on fruit stored in air. At the same time, sporulation of $M$. fructicola was slight to moderate and limited to the immediate area surrounding the original inoculation wound. The boundaries of the three lesions on each fruit were distinct and did not overlap. Fruit released 2to 4-fold less glucosamine from fungal chitin when stored in $15 \% \mathrm{CO}_{2}$ versus air (Fig. 1). However, the glucosamine content of inoculated fruit stored for 5 or $16 \mathrm{~d}$ in $15 \% \mathrm{CO}_{2}$ was 3-fold higher than that of those only incubated $72 \mathrm{~h}$ at $20{ }^{\circ} \mathrm{C}$ after inoculation. After $3 \mathrm{~d}$ ripening at $20{ }^{\circ} \mathrm{C}$, the lesions overlapped completely, sporulation was occurring over the entire fruit, and it was impossible to distinguish a difference between fruit stored previously in $15 \% \mathrm{CO}_{2}$ or air. However, the glucosamine content still showed a 2- to 3-fold lower level of infection in fruit stored previously in $15 \% \mathrm{CO}_{2}$ as compared to air stored fruit (Fig. 1).

Brown rot decay development in fruit inoculated $48 \mathrm{~h}$ before storage at $5{ }^{\circ} \mathrm{C}$ was less than on those fruit inoculated $72 \mathrm{~h}$ before storage at $5^{\circ} \mathrm{C}$, but these nectarines were also commercially unacceptable (Fig. 1). After $5 \mathrm{~d}$ cold storage, $9.5 \%$ and $6.2 \%$ of the epidermis of inoculated nectarines stored in air or air enriched with $15 \% \mathrm{CO}_{2}$, respectively, were infected. The extent of sporulation of $M$. fructicola was minute and sporulation was confined to the original area of inoculation. After $16 \mathrm{~d}$ storage at 5 ${ }^{\circ} \mathrm{C}$, the size of the infected area on inoculated fruit stored in $15 \% \mathrm{CO}_{2}$ was half the size of the lesions, and the extent of sporulation was 4fold less than the amount of sporulation on fruit stored in air at $5{ }^{\circ} \mathrm{C}$. After $3 \mathrm{~d}$ ripening at $20^{\circ} \mathrm{C}$, decay lesions covered $80 \%$ and $60 \%$ of the epidermis of fruit stored for $5 \mathrm{~d}$ in air or air with $15 \% \mathrm{CO}_{2}$, respectively (Fig. 1). The entire surface of fruit stored for $16 \mathrm{~d}$ at 5 ${ }^{\circ} \mathrm{C}$ plus $3 \mathrm{~d}$ at $20{ }^{\circ} \mathrm{C}$ was infected, regardless of the storage atmosphere. Monilinia fructicola sporulated rapidly at $20^{\circ} \mathrm{C}$ and there was no difference between air and $\mathrm{CO}_{2}$ treatments. In contrast to the infection data, fruit stored for 5 or $16 \mathrm{~d}$ in $\mathrm{CO}_{2}$ released the same amount of glucosamine as those incubated for $48 \mathrm{~h}$ at $20^{\circ} \mathrm{C}$

Fig. 1. (A-C) percent infected epidermis, (D-F) sporulation score, and (G-I) glucosamine released from the hydrolysis of cell walls of $M$. fructicola of nectarines inoculated (A, D, G) 24, (B, E, H) 48, and (C, F, I) $72 \mathrm{~h}$ before storage for 5 or $16 \mathrm{~d}$ at $5{ }^{\circ} \mathrm{C}$ in air or air enriched with $15 \% \mathrm{CO}_{2}$, and after an additional $3 \mathrm{~d}$ of ripening at $20^{\circ} \mathrm{C}$. Arrows denote the point of transfer to $20^{\circ} \mathrm{C}$. Sporulation score: $0=$ none, $1=$ slight, $2=$ moderate, $3=$ severe, and $4=$ very severe. Verticle bars represent SD values.

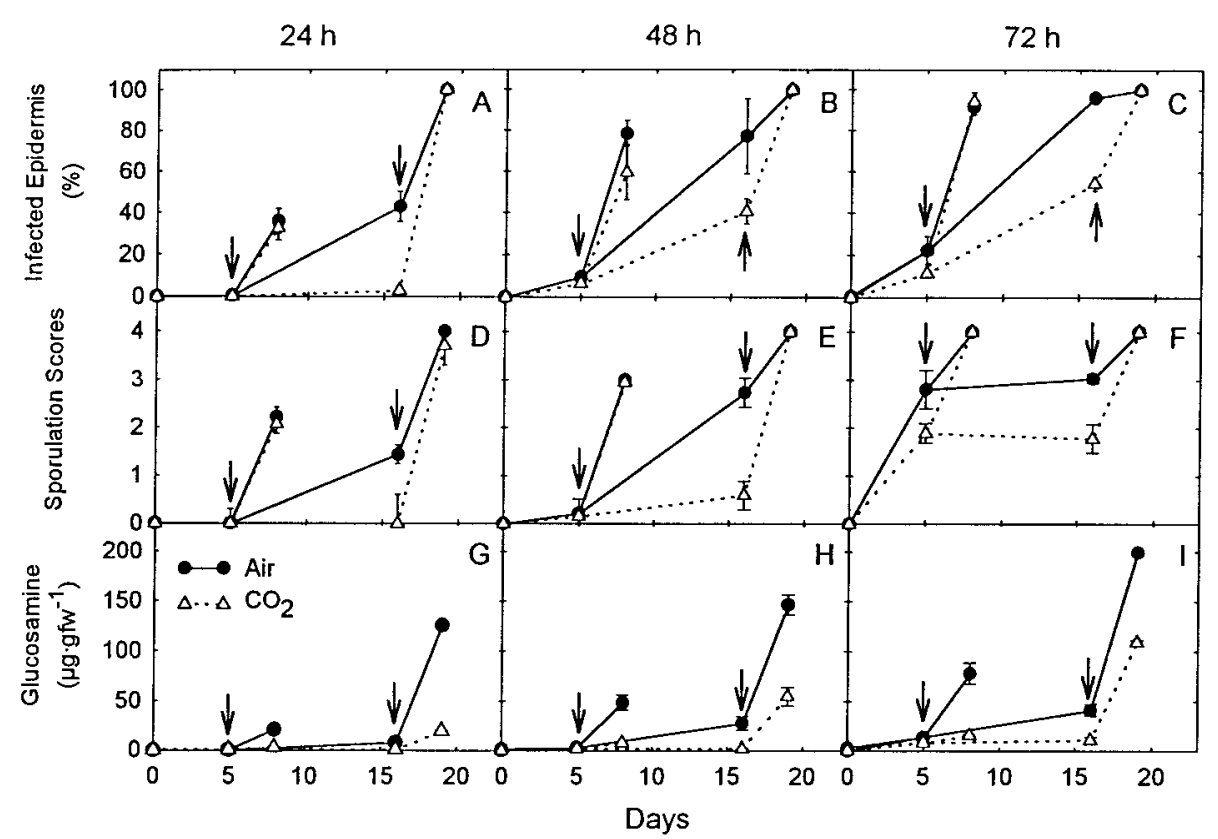


after inoculation. However, the glucosamine content of fruit stored in air for 5 or $16 \mathrm{~d}$ at $5^{\circ} \mathrm{C}$ was 2- and 10-fold greater than that of fruit stored in $15 \% \mathrm{CO}_{2}$, respectively. After 3 days ripening, the glucosamine content remained different between air and $\mathrm{CO}_{2}$-stored fruit, with 5- and 3-fold more glucosamine released from fruit previously stored for 5 or $16 \mathrm{~d}$ in air than in $\mathrm{CO}_{2}$, respectively.

There was very little visible decay development on the epidermis of fruit inoculated $24 \mathrm{~h}$ before $5 \mathrm{~d}$ storage in $15 \% \mathrm{CO}_{2}$ at $5^{\circ} \mathrm{C}$ (Fig. 1). Size of the lesions were the same as the original inoculation wounds and only $0.6 \mathrm{mg}$ of fungal cell wall glucosamine was released per gram of homogenized fruit tissue. Decayed area on fruit stored $5 \mathrm{~d}$ in air at $5{ }^{\circ} \mathrm{C}$ was 5- to 6-fold larger than on those stored in air enriched with $15 \% \mathrm{CO}_{2}$. Monilina fructicola did not sporulate during $5 \mathrm{~d}$ storage in air or air plus $15 \% \mathrm{CO}_{2}$ at $5^{\circ} \mathrm{C}$. The size of the decay lesions on inoculated fruit stored $16 \mathrm{~d}$ in air at $5{ }^{\circ} \mathrm{C}$ was 14 fold greater than on inoculated nectarines stored $16 \mathrm{~d}$ in air enriched with $15 \% \mathrm{CO}_{2}$. Sporulation of $M$. fructicola was arrested completely during $16 \mathrm{~d}$ storage in $15 \% \mathrm{CO}_{2}$; however, it was slight to moderate on inoculated nectarines stored $16 \mathrm{~d}$ in air only. There was no change in glucosamine content in fruit stored for $5 \mathrm{~d}$. After $16 \mathrm{~d}$ storage at $5^{\circ} \mathrm{C}$, the glucosamine content increased $\approx 10$-fold in fruit stored in air, but did not increase in fruit stored in $15 \% \mathrm{CO}_{2}$. After 3 d ripening at $20^{\circ} \mathrm{C}$, the size of the infected area and the amount of sporulation on fruit stored for $5 \mathrm{~d}$ were moderate and disease development rendered them unacceptable, regardless of the atmosphere treatment (Fig. 1). For fruit stored for $16 \mathrm{~d}$, decay lesions and sporulation developed rapidly and covered the entire fruit during the $3 \mathrm{~d}$ at $20^{\circ} \mathrm{C}$, regardless of the storage atmosphere (Fig. 1). Glucosamine content increased greatly at $20^{\circ} \mathrm{C}$, and the differences between fruit stored previously in air versus $15 \% \mathrm{CO}_{2}$ were greater than after cold storage. Amount of glucosamine released from fungal cell walls was 4- and 6-fold greater in fruit stored previously in air versus $\mathrm{CO}_{2}$ following $3 \mathrm{~d}$ ripening in air (Fig. 1).

EFFECT OF 15\% $\mathrm{CO}_{2}$ ON FRUIT QUALITY. Firmness of nectarines stored in air or air enriched with $15 \% \mathrm{CO}_{2}$ at $5^{\circ} \mathrm{C}$ for $5 \mathrm{~d}$ was not significantly different from firmness at harvest (Table 2). After 16 $\mathrm{d}$ storage, firmness of fruit stored in air decreased almost $8 \mathrm{~N}$ while firmness of nectarines stored in $15 \% \mathrm{CO}_{2}$ remained unchanged; however, neither difference was significant. Nectarines stored $16 \mathrm{~d}$ in air at $5^{\circ} \mathrm{C}$ and ripened for $3 \mathrm{~d}$ at $20^{\circ} \mathrm{C}$ were firmer than those stored $5 \mathrm{~d}$ at $5^{\circ} \mathrm{C}$ and ripened for $3 \mathrm{~d}$ at $20^{\circ} \mathrm{C}$ (Table 2). There was a similar but insignificant trend for fruit stored in $\mathrm{CO}_{2}$. Mean firmness of fruit stored in air enriched with $15 \% \mathrm{CO}_{2}$ was significantly greater than that of fruit treated with air (Table 1).

TSS and TA were not affected significantly by storage atmosphere (Tables 1 and 2). However, TSS increased and TA decreased during fruit ripening. No external or internal injuries, decay, discoloration or changes in the internal texture of fruit tissue were observed.

\section{Discussion}

Brown rot is a significant postharvest decay of stone fruit grown in California and results in considerable product losses. Stone fruit are often treated pre- and postharvest with registered fungicides to control M. fructicola. However, these chemicals often elicit development of resistance among pathogens after a period of application and may leave behind harmful residues (Adaskaveg and Ogawa, 1994). Ogawa et al. (1985) reported that the annual cost of preharvest fungicide applications and the estimated $1 \%$ loss of stone fruits before marketing from brown rot decay exceeded $\$ 50$ million in the six major California stone fruit-producing regions. Without fungicide sprays, stone fruit loss to brown rot may exceed 60\% (MacNab, 1975). CA regimes of low oxygen (2.2\%) enriched with $15 \%$ to $20 \%$ $\mathrm{CO}_{2}$ at low temperature $\left(0\right.$ to $\left.2{ }^{\circ} \mathrm{C}\right)$ usually reduce growth of $M$. fructicola (Sommer, 1985), but $15 \% \mathrm{CO}_{2}$ may cause internal damage to stone fruit after 2 to 6 weeks cold storage (Allen and Smock, 1937), with the exception of sweet cherries (DeVriesPaterson, et al., 1991).

In this study, a $16 \mathrm{~d}$ storage regime of air enriched with $15 \% \mathrm{CO}_{2}$ at $5{ }^{\circ} \mathrm{C}$ delayed the progression of disease in nectarines inoculated 24 or $48 \mathrm{~h}$ before CA storage, as judged by results of an accurate biochemical assay and visual methods of measuring brown rot decay development. There was no evidence of $\mathrm{CO}_{2}$-induced fruit injury, after $16 \mathrm{~d}$ plus $3 \mathrm{~d}$ ripening.

Results indicate that an atmosphere of air enriched with $15 \% \mathrm{CO}_{2}$ prolonged the lag period of infection and postponed the onset of disease in infected nectarines. In this study, each inoculated fruit

Table 2. Firmness, total soluble solids (TSS) and titratable acidity (TA) of 'Summer Red' nectarines stored in air or $15 \% \mathrm{CO}_{2}$ at $5{ }^{\circ} \mathrm{C}$.

\begin{tabular}{|c|c|c|c|c|c|c|}
\hline \multirow{2}{*}{$\begin{array}{l}\text { Days of } \\
\text { storage and } \\
\text { ripening }\end{array}$} & \multicolumn{2}{|c|}{$\begin{array}{l}\text { Firmness } \\
(\mathrm{N})\end{array}$} & \multicolumn{2}{|c|}{$\begin{array}{l}\text { TSS } \\
(\%)\end{array}$} & \multicolumn{2}{|c|}{$\begin{array}{l}\text { TA } \\
(\%)\end{array}$} \\
\hline & Air & $15 \% \mathrm{CO}_{2}$ & Air & $15 \% \mathrm{CO}_{2}$ & Air & $15 \% \mathrm{CO}_{2}$ \\
\hline 0 & $63.8 \mathrm{a}^{\mathrm{z}}$ & --- & $12.03 \mathrm{a}$ & --- & $0.90 \mathrm{a}$ & --- \\
\hline 5 & $62.6 \mathrm{a}$ & $59.9 \mathrm{a}$ & $11.13 \mathrm{a}$ & $10.66 \mathrm{a}$ & $0.78 \mathrm{a}$ & $0.83 \mathrm{a}$ \\
\hline $5+3$ & $26.3 \mathrm{c}$ & $38.1 \mathrm{~b}$ & $11.30 \mathrm{a}$ & $11.77 \mathrm{a}$ & $0.79 \mathrm{a}$ & $0.77 \mathrm{a}$ \\
\hline 16 & $55.9 \mathrm{a}$ & $62.2 \mathrm{a}$ & $11.87 \mathrm{a}$ & $10.90 \mathrm{a}$ & $0.66 \mathrm{a}$ & $0.74 \mathrm{a}$ \\
\hline \multirow[t]{2}{*}{$16+3$} & $39.0 \mathrm{~b}$ & $43.9 \mathrm{~b}$ & $11.63 \mathrm{a}$ & $11.70 \mathrm{a}$ & $0.59 \mathrm{a}$ & $0.68 \mathrm{a}$ \\
\hline & \multicolumn{2}{|c|}{ Mean } & \multicolumn{2}{|c|}{ Mean } & \multicolumn{2}{|c|}{ Mean } \\
\hline $15 \% \mathrm{CO}_{2}$ & \multicolumn{2}{|c|}{$55.6 \mathrm{a}$} & \multicolumn{2}{|c|}{$11.59 \mathrm{a}$} & \multicolumn{2}{|c|}{$0.79 \mathrm{a}$} \\
\hline Air & \multicolumn{2}{|c|}{$49.5 \mathrm{~b}$} & \multicolumn{2}{|c|}{$11.41 \mathrm{a}$} & \multicolumn{2}{|c|}{$0.74 \mathrm{a}$} \\
\hline \multicolumn{7}{|c|}{ Storage and ripening } \\
\hline 0 & \multicolumn{2}{|c|}{$63.8 \mathrm{a}$} & \multicolumn{2}{|c|}{$12.03 \mathrm{a}$} & \multicolumn{2}{|c|}{$0.90 \mathrm{a}$} \\
\hline 5 & \multicolumn{2}{|c|}{$61.2 \mathrm{a}$} & \multicolumn{2}{|c|}{$10.90 \mathrm{c}$} & \multicolumn{2}{|c|}{$0.81 \mathrm{ab}$} \\
\hline $5+3$ & \multicolumn{2}{|c|}{$32.2 \mathrm{c}$} & \multicolumn{2}{|c|}{$11.53 \mathrm{~b}$} & \multicolumn{2}{|c|}{$0.78 \mathrm{~b}$} \\
\hline 16 & \multicolumn{2}{|c|}{$59.0 \mathrm{a}$} & \multicolumn{2}{|c|}{$11.38 \mathrm{~b}$} & \multicolumn{2}{|c|}{$0.70 \mathrm{bc}$} \\
\hline $16+3$ & \multicolumn{2}{|c|}{$41.4 \mathrm{~b}$} & \multicolumn{2}{|c|}{$11.67 \mathrm{ab}$} & \multicolumn{2}{|c|}{$0.63 \mathrm{c}$} \\
\hline
\end{tabular}

${ }^{\mathrm{z} M e a n}$ separation within columns by Duncan's multiple range test $P \leq 0.05$ 
received over 500 spores per wound at three different locations on the fruit and at a depth of 2 to $3 \mathrm{~mm}$ under the epidermis. These injuries, for all practical purposes, are highly exaggerated and similarly injured fruit would usually be detected and discarded during sorting and packing. The conidia concentration of the inoculum $\left(5.4 \times 10^{4}\right.$ spores $\left./ \mathrm{mL}\right)$ was also higher than natural inoculum of $M$. fructicola on unripe or ripe fruit in typical orchards. However, in an unsprayed orchard, a mummy or an infected fruit peduncle has the potential of producing $4 \times 10^{6}$ and $10^{4}$ conidia with $80 \%$ to $90 \%$ viability, respectively (Byrde and Willetts, 1977).

Sizes of the brown rot lesions on the epidermis of fruit samples incubated for $24 \mathrm{~h}$ before storage in $15 \% \mathrm{CO}_{2}$ for $5 \mathrm{~d}$ were generally comparable with the sizes of lesions at the beginning of cold storage. Size of the lesions for those fruit incubated for 48 or $72 \mathrm{~h}$ were progressively greater. At $16 \mathrm{~d}$, size of the brown rot lesions was much greater in fruit incubated 48 or $72 \mathrm{~h}$ before cold storage as compared with $24 \mathrm{~h}$. However, as defined by the glucosamine assay, infection development in nectarines inoculated 24 or $48 \mathrm{~h}$ before 5 or $16 \mathrm{~d}$ storage in $15 \% \mathrm{CO}_{2}$ was insignificant during cold storage, but infection did develop in nectarines inoculated $72 \mathrm{~h}$ before 5 or $16 \mathrm{~d}$ storage in $\mathrm{CO}_{2}$. The discrepancy in the data for lesion size and glucosamine content may be due to the fact that one measures fungal growth only at the surface of the fruit while the other measures fungal chitin throughout the fruit volume.

The fungistatic effect of $15 \% \mathrm{CO}_{2}$ atmospheres inhibited or slowed disease development and sporulation of $M$. fructicola during cold storage, depending on the incubation period before storage in $\mathrm{CO}_{2}$ at $5^{\circ} \mathrm{C}$. However, after $3 \mathrm{~d}$ ripening in air at $20^{\circ} \mathrm{C}$, progression of the brown rot decay rendered all inoculated fruit commercially unacceptable, as also reported for sweet cherries (DeVries-Paterson et al. 1991).

Development of decay during ripening indicated that other measures, such as application of a reduced level of fungicides or biological control agents, would be needed to completely prevent decay development and extend the shelf life of peaches and nectarines in seasons with high disease pressure. The $\mathrm{CO}_{2}$ atmospheres may arrest sporulation and prevent spread of decay from infected to healthy fruit during transportation and distribution. However, a second sorting of fruit for brown rot decay upon transfer to ripening temperatures may be needed to prevent the spread of brown rot to healthy fruit during ripening.

None of the noninoculated fruit stored for 5 or $16 \mathrm{~d}$ at $5{ }^{\circ} \mathrm{C}$ in air enriched with $15 \% \mathrm{CO}_{2}$ and subsequently ripened, exhibited any external or internal injuries, mealiness or decay lesions. Their postharvest fruit quality attributes were comparable to nectarines stored in air at $5^{\circ} \mathrm{C}$ and subsequently ripened at $20^{\circ} \mathrm{C}$ for $3 \mathrm{~d}$, except that nectarines stored in $15 \% \mathrm{CO}_{2}$ were firmer. These results agree with those of Youssef and Mitcham (1997) who found that 'Sparkle' peaches tolerated a $15 \mathrm{~d}$ exposure to $15 \% \mathrm{CO}_{2}$ at $5^{\circ} \mathrm{C}$.

Measurement of glucosamine released from fungal chitin of inoculated nectarines described the progression of brown rot infection (fungal hyphae advancement) more accurately than visual measurement of the decayed area on the fruit epidermis at the onset of disease and its early progression. Fungal chitin was detected after only $24 \mathrm{~h}$ incubation at $20^{\circ} \mathrm{C}$ in inoculated fruit. Decay lesions could be detected visually only after $72 \mathrm{~h}$ incubation at $20^{\circ} \mathrm{C}$. The glucosamine assay also described the extent of brown rot decay development in inoculated fruit stored $5 \mathrm{~d}$ in $\mathrm{CO}_{2}$ at $5^{\circ} \mathrm{C}$ and ripened $3 \mathrm{~d}$ at $20^{\circ} \mathrm{C}$ more accurately than size measurement of decay lesions. A more accurate means of determining fungal growth in the fruit may provide a useful tool for researchers studying the impact of fungicidal or fungistatic treatments. Perhaps this precise and accu- rate assay could be automated for rapid determination of brown rot inoculum in orchards and the extent of infection in harvested fruit. It may guide growers and packinghouse operators to pre- or postharvest control measures.

Results demonstrate that 'Summer Red' nectarines tolerated a 16 d exposure to $15 \% \mathrm{CO}_{2}$ at $5{ }^{\circ} \mathrm{C}$. The $\mathrm{CO}_{2}$ atmosphere reduced development of brown rot decay and sporulation of $M$. fructicola during $\mathrm{CA}$ storage. However, because the $\mathrm{CO}_{2}$ atmospheres are fungistatic and decay development is rapid during the ripening period, this technique cannot be used as a single method for decay control in years with high disease pressure. Fruit inoculated $24 \mathrm{~h}$ before storage would be similar to nectarines and peaches packed commercially with careful handling and sorting by experienced packinghouse operators. To optimize the benefit of CA, packers are advised to harvest their fruit carefully, hydrocool them using cold, chlorinated water, sort out injured and decayed fruit during packing, and place them under $\mathrm{CO}_{2}$ atmospheres at 0 to $5^{\circ} \mathrm{C}$ within $24 \mathrm{~h}$ of harvest for short term storage, transportation, and distribution.

\section{Literature Cited}

Adaskaveg, J.E. and J.M. Ogawa. 1994. Penetration of iprodione into mesocarp fruit tissue and suppression of gray mold and brown rot of sweet cherries. Plant Dis. 78:293-296.

Allen, F.W. and R.M. Smock. 1937. Carbon dioxide storage of apples, pears, plums and peaches. Proc. Amer. Soc. Hort. Sci. 35:193-199.

Bishop, R.H., C.L. Duncan, G.M. Evancho, and H. Young. 1982. Estimation of fungal contamination in tomato products by a chemical assay for chitin. J. Food Sci. 47:437-444.

Byrde, R.J.W. and H.J. Willets. (eds.). 1977. The brown rot fungi of fruit, their biology and control. Pergamon Press, Oxford, New York.

DeVries-Paterson, R.M., A.L. Jones, and A.C.Cameron. 1991. Fungistatic effects of carbon dioxide in a package environment on the decay of Michigan sweet cherries by Monilinia fructicola. Plant Dis. 75:943-946.

English, H. and F. Gerhardt. 1942. Effect of carbon dioxide and temperature on the decay of sweet cherries under simulated transit conditions. Proc. Amer. Soc. Hort. Sci. 40:172-176.

Jarvis, B. 1977. A chemical method for the estimation of mould in tomato products. J. Food Technol. 12:581-591.

Kader, A.A., M.A. El-Goorani, and N.F. Sommer. 1982. Postharvest decay, respiration, ethylene production, and quality of peaches held in controlled atmospheres with added carbon monoxide. J. Amer. Soc. Hort. Sci. 107:856-859.

MacNab, A.A. 1975. Stone fruit disease reports. Fungicide Nematicide Tests 30:39-48.

Northover, J. and R.F. Cerkauskas. 1992. Detection and control of Monilinia fructicola latent infections in plum. Phytopathology 82(10): 1069 (abstr.).

Ogawa, J.M., B.T. Manji, and R.M. Sonoda. 1985. Management of the brown rot disease on stone fruits and almonds in California, p. 5-8. In: T.J. Burr (ed.). Proc. Brown Rot of Stone Fruit Workshop, New York State Agr. Expt. Sta., Geneva.

Osorio, J.M., J.E. Adaskaveg, and J.M. Ogawa. 1993. Comparative efficacy and systemic activity of iprodione and the experimental anilide E-0858 for control of brown rot on peach fruit. Plant Dis. 77:1140-1143.

Ride, J.P. and R.B. Drysdale. 1972. A rapid method for the chemical estimation of filamentous fungi in plant tissue. Physiol. Plant Pathol. 2:7-15.

Sommer, N.F. 1985. Role of controlled environments in suppression of postharvest diseases. Can. J. Plant Pathol. 7:331-339.

Sommer, N.F., R.J. Fortlage, J.R. Buchanan, and A.A. Kader. 1981. Effect of oxygen on carbon monoxide suppression of postharvest pathogens of fruits. Plant Dis. 65:347-349.

Youssef, S.E. and E.J. Mitcham. 1997. Hot water and controlled atmosphere storage for controlling brown rot of peaches and apricots. Egyptian J. Appl. Sci. 12:96-114. 